\title{
Does a Short Brand Story on the Package Affect Consumers' Brand Responses?
}

\author{
Eeva Solja, Veronica Liljander, and Magnus Söderlund
}

\begin{abstract}
The persuasiveness of stories and their influence on consumers have been acknowledged within the fields of advertising, tourism, and services. Despite these findings, stories have not caught the attention that they deserve in the product and brand literature. Nothing indicates that stories would have less of an effect when applied to brands. It is especially intriguing that stories - of various kinds - have become ubiquitous on product packaging in practice. Yet there are no studies on the effect of such stories on the consumer's response to the brand. Can it be taken for given that consumers will react more positively to a package when some of the brand information is presented in story form? Packages have limited space and are filled with information required by law, which is not the case for advertisements. Thus, findings from advertising cannot be directly applied to packing. Currently, there is scant empirical research that directly investigates the impact of short brand stories on consumer responses, and such research is particularly lacking on packaging, where stories are ubiquitously used in practice.

This study uses a between-subjects experiment to test hypotheses pertaining to the impact of a short brand story communicated on a packaging on consumers' brand responses. The chapter shows that a company originated short brand story, which is added to the marketing communication of an existing, fast-moving consumer brand packaging produces a higher level of on brand attitude, perceived value, and behavioral intentions as opposed to when no story is present.

The study contributes to the product and brand literature in three ways. First, it provides empirical evidence of the effects of brand stories on packaging. Second, it shows that even a short story - within the limited space available on packaging - is capable of influencing consumers' brand responses. Third, it widens the application context of previous findings by examining a FMCG. The major practical implication is that managers may consider packaging as a channel to communicate short brand stories.
\end{abstract}

\author{
E. Solja $(\bowtie) \bullet$ V. Liljander \\ Hanken School of Economics, CERS, Helsinki, Finland \\ e-mail: eeva.solja@hanken.fi; veronica.liljander@hanken.fi \\ M. Söderlund \\ Stockholm School Economics, Stockholm, Sweden \\ e-mail: magnus.soderlund@hhs.se
}

